УДК 159.942

DOI:

Леся Височан, доктор педагогічних наук, доцент кафедри фахових методик і технологій початкової освіти Прикарпатського національного університету імені Василя Стефаника

Ліліана Хімчук, доктор педагогічних наук, дочент кафедри фахових методик і технологій початкової освіти Прикарпатського національного університету імені Василя Стефаника

Руслана Романишин, доктор педагогічних наук, доцент кафедри фахових методик $і$ технологій початкової освіти Прикарпатського наџіонального університету імені Василя Стефаника

\title{
АКТИВІЗАЦІЯ ПІЗНАВАЛЬНОЇ ДІЯЛЬНОСТІ УЧНІВ ПОЧАТКОВОЇ ШКОЛИ: АКЦЕНТИ НАУКОВО-ПЕДАГОГІЧНОГО ДИСКУРСУ
}

У статті здійснено синтезований репрезентативний аналіз науково-педагогічного дискурсу проблеми формування пізнавальної активності учнів молодщих класів. Систематизовано продуктивні ідеї, погляди щодо розробки науково-теоретичних і організаційно-методичних аспектів означеної проблеми. Визначено два пріоритетні наративи ї осмислення психолого-педагогічною наукою. Перший акцентує на позитивних змінах, які відбуваються у загальному розвитку учнів молодших класів під впливом розвивального навчання; другий - фокусує на тому, щз їхня пізнавальна активність зумовлюється індивідуальністю як стрижневим компонентом психофізіологічного розвитку.

Ключові слова: психолого-педагогічна наука; науково-педагогічний дискурс; пізнавальна активність; учні початкової иколи; вивчення особистості.

Jim. 12.

Lesya Vysochan, Doctor of Sciences (Pedagogy), Associate Professor of the Professional and Methods and Technologies of Elementary Education Department, Vasyl Stefanyk Precarpathian National University

Liliana Khimchuk, Doctor of Sciences (Pedagogy), Associate Professor of the Professional and Methods and Technologies of Elementary Education Department, Vasyl Stefanyk Precarpathian National University

Ruslana Romanyshyn, Doctor of Sciences (Pedagogy), Associate professor of the Professional and Methods and Technologies of Elementary Education Department, Vasyl Stefanyk Precarpathian National University

\section{ACTIVATION OF COGNITIVE ACTIVITY OF PRIMARY SCHOOLSTUDENTS: ACCENTS OF SCIENTIFIC AND PEDAGOGICAL DISCOURSE}

The article presents a representative synthesized analysis of the Ukrainian scientific and pedagogical discourse of the problem of forming the cognitive activity of junior students. The productive ideas and views on the development of scientific-theoretical and organizational-methodological aspects of this problem are systematized. Two priority narratives of its comprehension by psychological and pedagogical science are determined. The first emphasizes the positive changes that occur in the overall development of students under the influence of developmental learning. They are a natural consequence of changes in the content of education and the direction of pedagogical efforts to organize the active activities of the child. The second narrative focuses on the fact that the cognitive activity of the younger student is determined by the personality as a core component of psychophysiological development.

It is revealed that in the Ukrainian scientific and pedagogical discourse the consolidated position has been formed, according to which the activity of an elementary school student is expressed through the various types of activity - cognitive, educational, social, leisure. At the same time, scientists agree that educational activity is of exceptional importance, because the primary school age is the period of the most intensive personal formation, so it is a specific form of individual activity. In this context, the emphasis on the need to focus pedagogical efforts on the transfer of ready-made knowledge to the development of creative cognitive abilities of children and the formation of skills of independent thinking and the acquisition of new knowledge is quite natural. The conditions of development

(C) Л. Височан, Л. Хімчук,

Р. Романишин, 2021 


\section{АКТИВІЗАЦІЯ ПІЗНАВАЛЬНОЇ ДІЯЛЬНОСТІ УЧНІВ ПОЧАТКОВОЇ ШКОЛИ: АКЦЕНТИ НАУКОВО-ПЕДАГОГІЧНОГО ДИСКУРСУ}

of cognitive activity of pupils of junior classes are shown: creation of educational and subject environment; ensuring the emotional appeal of learning; use of optimal systems of training creative exercises and search-heuristic tasks.

Keywords: psychological and pedagogical science; scientific and pedagogical discourse; cognitive activity; primary school students; study of personality.

П остановка проблеми. Активізація освітнього процесу в сучасній школі стала однією 3 ключових парадигм розвитку української системи освіти. Вона інтегрує його основні компоненти (зміст, мета, методи, форми, засоби) та становить важливий механізм їхньої дії і досягнення успіху. Ця проблема має глибокі гносеологічні коріння, її фундаментальні засади розроблялись Я. Коменським, А. Дістервегом, Г. Песталоцці, К. Ушинським, іншими класиками зарубіжної та української педагогіки. Зокрема, Я. Коменський у класичній праці “Велика дидактика" доводив необхідність всіма засобами розвивати в дітей природну активність як важливий чинник активізації їхнього пізнання i навчання [6, 26]. А славетний знавець дитячої душі К. Ушинський одним із перших сформулював постулат, який утвердився в теорії і практиці навчання: “Варто пам'ятати, що потрібно передавати учневі не тільки певні знання, але й розвивати в ньому бажання i здатність самостійно, без учителя, засвоювати нові знання”, [12, 500].

За сучасних умов активізація пізнавальної діяльності набула якісно нового виміру в руслі пошуку шляхів і методів створення такої системи навчальної роботи, яка сприяла б ефективній розумовій діяльності та вмінню самостійно, творчо набувати знання, розв'язувати практичні завдання за стандартних і непередбачуваних ситуацій. Означена проблема набуває практичної значущості в руслі динамічного розвитку інноваційних технологій, коли доступ до інформації (фактів) істотно полегшується, тому особа повинна їх постійно сепарувати, переосмислювати, а отже, повсякчас самонавчатися, самовдосконалюватися.

В означеному ключі актуалізується необхідність 3'ясування основних аспектів науково-педагогічного дискурсу щодо розвитку пізнавальної активності здобувача освіти. Пропонуємо розглянути цю проблему в контексті їі формування в учнів молодших класів, яка значною мірою фокусує основні аспекти і тенденції ї осмислення сучасною педагогічною наукою.

Аналіз останніх досліджень. Проблема пізнавальної активності має міждисциплінарний характер. Вона активно досліджується у психології в проєкції розвитку особистості (Л. Волинська, В. Мерлін, В. Моляко, Л. Обухова, 3. Огороднійчук, М. Савчин, О. Скрипченко, та ін.) та в загальній дидактиці як стрижень, що пов'язує різні компоненти формування і розвитку здобувача освіти (О. Козіна, І. Лернер та ін.). Формування пізнавальної активності учнів початкової школи розглядається в наукових працях у двох основних площинах: 1) удосконалення методів і засобів їхнього навчання (Н. Бібік, О. Біда, К. Гончарова, Л. Данилова, О. Киричук, Г. Ковальчук, І. Мозуль, Л. Нарочна, О. Савченко, Г. Щукіна та ін.); 2) підготовка майбутніх учителів до професійної діяльності в цьому напрямі (В. Вертугіна В. Горощенко, Н. Граматик, В. Грицик, К. Гуз, О. Дюкова, І.Жаркова, Л. Мельчаков, Л. Моторна, О. Половіна, І. Степанов та ін.). 3 їхніх досліджень випливає безліч суголосних та контроверсійних, подекуди амбівалентних поглядів на порушену проблему. Ці рефлексії потребують систематизації і предметного аналізу задля визначення загальної домінуючої тенденції та інноваційних

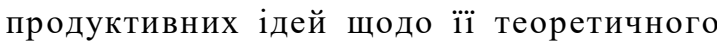
осмислення і практичного розв’язання.

Метою статті $\epsilon$ аналіз науково-педагогічного дискурсу проблеми формування пізнавальної активності учнів початкової школи задля систематизації поглядів, ідей, думок учених та визначення їхньої продуктивності й перспектив теоретичного осмислення і розробки методичних інструментів практичного розв'язання означеної проблеми.

Виклад основного матеріалу. У психологічній науці активність розглядається у контексті двох пріоритетних підходів вивчення особистості особистісного та діяльнісного. Прихильники першого в центр уваги ставлять особистість 3 їі індивідуальними властивостями і характеристиками. Активність у цьому випадку розглядається як риса особистості. Концепція діяльнісного підходу фактично ототожнює поняття-феномени “активність” і “діяльність”. Пізнавальна активність у цьому випадку зумовлюе ефективність пізнавальної діяльності та виявляється у спрямованості й стійкості пізнавальних інтересів (М. Савчин [11]).

Позицію учених-дидактів щодо порушеної проблеми концептуалізував I. Лернер, який стверджував, що в центрі дидактики, психології навчання і предметних методик стоїть проблема виховання пізнавальної активності й самостійності учнів. Ї̈і увінчує формування здатності самостійно випрацьовувати діалектико-матеріалістичний світогляд та прагнення до активної, творчої діяльності в усіх видах розумової і фізичної праці. 


\section{АКТИВІЗАЦІЯ ПІЗНАВАЛЬНОЇ ДІЯЛЬНОСТІ УЧНІВ ПОЧАТКОВОЇ ШКОЛИ: АКЦЕНТИ НАУКОВО-ПЕДАГОГТЧНОГО ДИСКУРСУ}

У такому розрізі виникають нові аспекти розробки методів навчання та організаційних форм їхньої побудови [7, 34].

Новітні психолого-педагогічні дослідження [1$2 ; 5 ; 8-10]$ уможливлюють визначити пізнавальну активність як свідоме, цілеспрямоване, вольове, виконання розумової роботи для оволодіння знаннями і вміннями, необхідними для навчальної роботи та практичної (професійної) діяльності. За такого підходу поняття “активність” суголосне поняттю “готовність” як здатність і прагнення до енергійного, ініціативного оволодіння знаннями та докладання вольових зусиль для досягнення певних цілей.

Активний характер навчання становить надійну основу розвитку пізнавальної активності учнів початкової школи, яка починає формуватися у 6-9 років. Важливу роль в оволодінні ними способами пізнавальної діяльності відіграють дії за зразком і аналогією. Профільні дослідження і педагогічний досвід засвідчують, що за певних умов учні 1-2-х класів починають виявляти здатність виконувати завдання, які вимагають пошуку, розмірковування, самостійних розумових зусиль. Тому інтенсифікація навчальної діяльності стає необхідною умовою наступності навчання і розвитку школярів [1-2; 8].

У ракурсі сучасних освітніх парадигм зі студій згаданих та інших українських учених-педагогів (В. Горощенко, Н. Граматик, В. Грицик, К. Гуз, Л. Данилова, Жаркова, О. Киричук, Г. Ковальчук, Л. Мельчаков, І. Мозуль, Л. Моторна, О. Половіна, О. Савченко) випливає два важливі наративи осмислення порушеної проблеми. Перший акцентує на позитивних змінах, які відбуваються у загальному розвитку учнів молодших класів під впливом розвивального навчання. Вони $\epsilon$ закономірним наслідком змін у змісті навчання та орієнтації вчителів на організацію активної діяльності дитини. У такий спосіб доводиться, що пізнавальна активність $€$ найважливішою умовою успішності їхнього навчання і розвитку. Другий наратив фокусує на тому, що пізнавальна активність школяра зумовлена його індивідуальністю як стрижнем психофізіологічного розвитку. Тому індивідуального підходу потребує кожна дитина, яка становить унікальний цілісний мікрокосм.

В українському науково-педагогічному дискурсі сформувалася доволі сконсолідована позиція, згідно з якою активність учня початкової школи виражається через різні види діяльності пізнавальну, навчальну, соціальну, дозвіллєву. При цьому навчальна діяльність набуває виняткового значення, адже молодший шкільний вік є періодом найбільш інтенсивного особистісного формування, тож вона виступає специфічною формою індивідуальної активності. У такому контексті цілком закономірно змінюються акценти 3 необхідності зосередження педагогічних зусиль iз передачі готових знань на розвиток творчих пізнавальних можливостей дітей та формування у них навичок самостійного мислення і набуття нових знань.

Репрезентативно-синтезований аналіз студій із досліджуваної проблеми свідчить, що організаційно-методична реалізація ідей розвитку пізнавальної активності учнів початкової школи не відповідає (поступається) достатньо високому рівню науково-теоретичної розробки цієї проблеми. Це суперечить аксіоматичній установці, відповідно до якої досягнення успіху в організації освітнього процесу апріорі неможливо без належного методичного забезпечення. Це повною мірою стосується активізації пізнавальної діяльності, яка створює умови для самореалізації учнів, сприяє підвищенню їхніх теоретичних знань та розвитку інтелектуальних творчих здібностей.

Означені положення окреслюють орієнтири професійно-педагогічної діяльності вчителів та підготовки майбутніх педагогів до активізації пізнавальної діяльності учнів початкової школи. Вони мають чітко розуміти, що формування пізнавальної активності-надважливий, складний, тривалий процес, який вимагає створення спеціальних умов та вмілого педагогічного керівництва. Це зобов'язує вчителя під час формування пізнавальної активності учнів ураховувати особливості їхньої навчальної діяльності як об'єкта інтересу, зокрема, присутність елементів новизни у змісті навчального матеріалу, функційний зміст навчальної праці, форми організації навчальної діяльності тощо (Н. Бібік $[1,12]$; О. Савченко [10, 5-23])

Вважаємо, що до осмисленні методичних напрацювань та самостійної розробки методики організації освітнього процесу необхідно підходити з установки, згідно з якою залучення кожного учня в активний пізнавальний процес передусім потребує створення навчально-предметного середовища, яке забезпечує можливості вільного доступу до різних джерел інформації, спілкування 3 однолітками, творчу співпрацю у розв'язанні різних проблем.

Для цього, як випливає з аналізу Державного стандарту початкової освіти [4] та спеціальних психолого-педагогічних студій (Л. Данилова, I. Демічева, О. Митник, І. Мозуль, Н. Смолянюк, О. Старинська та ін. [1-3; 5; 7-10]), необхідно 


\section{АКТИВІЗАЦІЯ ПІЗНАВАЛЬНОЇ ДІЯЛЬНОСТІ УЧНІВ ПОЧАТКОВОЇ ШКОЛИ: АКЦЕНТИ НАУКОВО-ПЕДАГОГІЧНОГО ДИСКУРСУ}

створити низку важливих умов. Першою i головною $є$ розуміння учнем змісту і значення навчального матеріалу. Для цього педагог має 3'ясувати: у чому саме сьогодні варто переконати учнів; якими шляхами, методами, прийомами, засобами краще й ефективніше розкрити їм суть і значення навчального матеріалу в перспективі. Другою умовою $є$ присутність новизни як у його змісті, так і методиці розгляду. Відмовляючись від зайвого повторювання відомих істин, треба розширювати обрії пізнання учнів та вчити їх шукати і знаходити у, здавалося б, відомій інформації нове, раніше не відоме, але істотне для iii глибшого розуміння.

Третьою важливою умовою формування пізнавальної активності дитини є забезпечення емоційної привабливості навчання. Потрібно прагнути того, щоб здобуті на уроках знання викликали емоційний відгук, активізували моральні, інтелектуальні, естетичні почуття, стимулювати потребу в практичній реалізації здобутих знань. Варто пам'ятати, що пізнавальна активність учнів формується лише тоді, коли вчитель не монотонно оповідає певні істини, а активізує пізнавальну діяльність дітей та включає до процесу розумового творчого пошуку почергове розв'язання пізнавальних завдань.

Четвертою умовою розвитку пізнавальної активності є використання оптимальних систем тренувальних творчих вправ і пошуковоевристичних завдань, що мають сприйматися учнем не як чергові порції засвоєння програмового матеріалу, а як виклики, які він добровільно приймає і свідомо прагне їх якнайкраще здолати. За такого підходу пізнавальний інтерес спирається на об'єктивні цінності навчання та додає йому інтенсивності, рухливості, продуктивності і сприятливого емоційно-інтелектуального тонусу. Дотримання цих умов дає змогу будувати навчально-пізнавальну діяльність у логічній послідовності, яка визначається формулою: “цікавлюся - знаю - вмію" [8].

Означені теоретичні установки та умови органічно відповідають компетентісноорієнтованому підходу, що став одним зі стрижнів сучасної системи освіти України. Його ідеї наскрізь пронизують Державний стандарт початкової освіти, зокрема програми дисциплін [4], які передбачають організацію навчальнопізнавальної діяльності учнів на основі сучасних освітніх технологій. Це орієнтує на побудову освітнього процесу у такий спосіб, щоб кожна дитина почувалася дослідником, який самостійно здобуває знання та шукає істину разом із товаришами і вчителем. Така установка максимально активізує навчально-пізнавальну діяльність учня та забезпечуючи його психологічний комфорт і творчу самореалізацію.

Предметний аналіз наукового й організаційнометодичного доробку з досліджуваної проблеми уможливлює стверджувати потребу більш предметної теоретичної розробки й увиразнення деяких базових пріоритетів і орієнтирів пізнавальної діяльності учнів початкової школи як важливого чинника і напряму формування їхньої пізнавальної активності. Для розв'язання цього завдання актуалізуємо концепт, постульований радянським педагогом М. Даниловим, якого вважають одним із перших дослідників проблеми пізнавальної активності дітей. Її сутність учений бачив у потребі й умінні учнів самостійно мислити, їхній здатності орієнтуватися в новій ситуації, самостійно виявляти важливі проблеми і завдання та знаходити підходи до їх розв'язання [138].

У проєкції формування знань із різних навчальних дисциплін, приміром, "Природознавства", пізнавальна самостійність учнів початкової школи може виявлятися в уміннях самостійно аналізувати й пояснювати певні процеси і явища, які відбуваються в неживій та живій природі, уміннях виконувати запропоновані вчителем навчальні завдання без сторонньої допомоги, а завдяки своєму критичному розуму, здатності висловлювати власну думку, незалежну від суджень інших. Таким чином, самостійність учнів на уроках природознавства виявлятиметься як здатність розуміти матеріал та застосовувати його в нових видах самостійних завдань.

У такому руслі не втратила науковотеоретичної і практичної актуальності обгрунтована П. Підкасистим за матеріалами теоретико-експериментальних досліджень модель самостійної діяльності учня, що передбачає постановку дидактичних i пізнавальних завдань, урахування специфіки формування їхніх самостійних дій. Доволі продуктивною $\epsilon$ розроблена вченим практичноорієнтована класифікація різних видів самостійної роботи школярів [див.: 9].

Варто враховувати ту важливу обставину, що самостійність й активність учнів початкової школи в освітньому процесі - феномени взаємопов'язані, але не тотожні. Активність може не включати самостійності, коли, до прикладу, учень виявляе активність, але не виявляє самостійності при несвідомому читанні, механічному списуванні, копіюванні виробу на уроках ручної праці тощо. У процесі навчання самостійність виявляється в активності, спрямованій на набуття нових знань і 
практичних умінь. Це пов'язане з формуванням пізнавальних інтересів та інших мотивів, які стимулюють і зміцнюють вольові зусилля для виконання тих чи інших завдань [2, 26].

Висновки і перспективи подальших досліджень. 3 репрезентативно-синтезованого аналізу науково-педагогічного дискурсу випливає, що активізація пізнавальної діяльності учнів початкової школи передбачає свідоме, вольове, цілеспрямоване виконання розумової творчої, самостійної роботи, спрямованої на оволодіння знаннями, уміннями, навичками їхнього використання в навчальній та іншій практичній діяльності. У сучасному дискурсі утвердилася ініційована ще радянськими вченими стрижнева ідея, згідно з якою пізнавальна активність супроводжує будь-яку самостійну дію, що завжди спрямована на засвоєння нових знань, передбачає готовність до пошукової роботи.

Перспективи студій у вимірі порушеної проблеми вбачаємо у науково-теоретичному обгрунтуванні необхідності посилення в процесі підготовки майбутнього вчителя початкових класів орієнтирів і установок, згідно з якими він має давати учням не готові знання, а вчити їх активного пошуку шляхів і способів оволодіння ними. Це має стимулювати підготовку дидактичних матеріалів, які б інтегрували інноваційні методики, орієнтовані на підвищення пізнавальної активності дітей і розвиток їхніх творчих здібностей як необхідних умов осмисленого засвоєння знань.

\section{ЛІТЕРАТУРА}

1. Бібік Н. М. Формування пізнавальних інтересів молодших школярів: монографія. Київ: ВІПОЛ, 1998. 199 с.

2. Вікова і педагогічна психологія: навчальний посібник / О. В. Скрипченко, Л. В. Волинська, 3. В. Огороднійчук. Київ: Каравела, 2008. 400 с.

3. Данилов М. А. Воспитание у школьников самостоятельности и творческой активности в процессе обучения. Советская педагогика. 1961. № 8. C. 32-42.

4. Державний стандарт початкової освіти. 2018. URL: https://www.kmu.gov.ua/ua/npas/prostandartu- pochatkovoyi-osviti

5. Коломієць А. В. Особистісно орієнтоване навчання - шлях до формування інноваційної особистості: методчний посібник. Хмельницький, $2014.98 \mathrm{c}$.

6. Коменский Я.А. Великая дидактика. Москва: Наркомпрос, 1939. 318 c. URL: www.twirpx.com.

7. Лернер I. Я. Дидактические основы познавательной самостоятельности учащихся при изучении гуманитарных дисциплін. Москва, 1991.278 c

8. Парійчук I. Розвиток пізнавальної активності учнів початкових класів на уроках " $Я$ у світі”. Актуальні проблеми дошкільної та початкової освіти: збірник наукових праць. Житомир: ЖДУ ім. І. Франка, 2017. С. 134"141.

9. Пидкасистый П. И. Самостоятельная деятельность учащихся: Дидактический анализ процесса и структуры воспроизведения и творчества. Москва: Педагогика, 1972. 183 с.

10. Савченко О. Я. Умій вчитися: навчальний посібник. Київ: Освіта, 1998. 192 с.

11. Савчин М. В. Педагогічна психологія. Київ: Альма-матер, 2007. 424 с.

12. Ушинский К. Д. Избранные педагогические сочинения. Москва: Педагогика, 1974. 1024 с.

\section{REFERENCES}

1. Bibik, N. M. (1998). Formuvannia piznavalnykh interesiv molodshykh shkoliariv: monohrafiia [Formation of cognitive interests of junior students]. Kyiv, 199 p. [in Ukrainian].

2. Vikova i pedahohichna psykholohiia: navchalnyi posibnyk (2008). [Age and pedagogical psychology]. (Ed.). O. V.Skrypchenko,L. V. Volynska,Z. V.Ohorodniichuk. Kyiv, 400p. [in Ukrainian].

3. Danylov, M. A. (1961). Vospytanye u shkolnykov samostoiatelnosty y tvorcheskoi aktyvnosty $\mathrm{v}$ protsesse obuchenyia [Education of schoolchildren independence and creative activity in the learning process]. Soviet pedagogy, Vol. 8 . pp. 32-42. [in Russian].

4. Derzhavnyi standart pochatkovoi osvity (2018). [State standard of primary education]. Available at: https://www.kmu.gov.ua/ua/npas/prozatverdzhennya-derzhavnogo-standartupochatkovoyi-osviti [in Ukrainian].

5. Kolomiiets, A. V. (2014). Osobystisno oriientovane navchannia - shliakh do formuvannia innovatsiinoi osobystosti: metodchnyi posibnyk [Personally oriented learning - a way to form an innovative personality: a guide]. Khmelnytskyi, 98 p. [in Ukrainian].

6. Komenskyi, Ya.A. (1939). Velykaia dydaktyka [Great didactics]. Moscow, 318 p. Available at: www.twirpx.com. [in Russian].

7. Lerner, I. Ya. (1991). Dydaktycheskye osnovy poznavatelnoi samostoiatelnosty uchashchykhsia pry yzuchenyy humanitarnykh dystsyplyn [Didactic bases of cognitive independence of students in the study of humanities]. Moscow, 278 p. [in Russian].

8. Pariichuk, I. (2017). Rozvytok piznavalnoi aktyvnosti uchniv pochatkovykh klasiv na urokakh "Ia u sviti" [Development of cognitive activity of 
primary school students in the lessons "I am in the world"]. Current issues of preschool and primary education: a collection of scientific papers. Zhytomyr, pp. 134-141. [in Ukrainian].

9. Pidkasistyiy, P. I. (1972). Samostoyatelnaya deyatelnost uchaschihsya: Didakticheskiy analiz protsessa i strukturyi vosproizvedeniya i tvorchestva [Independent activity of students: Didactic analysis of the process and structure of reproduction and creativity]. Moscow, 183 p. [in Russian].
10. Savchenko, O. Ya. (1998). Umii vchytysia: navchalnyi posibnyk [Be able to learn: a textbook]. Kyiv, 192 p. [in Ukrainian].

11. Savchyn, M. V. (2007). Pedahohichna psykholohiia [Pedagogical psychology]. Kyiv, 424 p. [in Ukrainian].

12.Ushynskyi, K. D. (1974). Izbrannye pedahohycheskie sochynenyia [Selected pedagogical works]. Moskva, 1024 p. [in Russian].

Стаття надійшла до редакції 07.10.2021

УДК 94(477.8):355“1944”

DOI:

Микола Галів, доктор педагогічних наук, доцент кафедри історії України Дрогобииького державного педагогічного університету імені Івана Франка

Олександра Свйонтик, кандидат педагогічних наук, доиент кафедри загальної педагогіки та дошкільної освіти Дрогобииького державного педагогічного університету імені Івана Франка Мирослав Ющишин, здобувач другого (магістерського) рівня вищої освіти Дрогобицького державного педагогічного університету імені Івана Франка

\section{ОСВІТНІЙ ПРОЦЕС У ЛЬВІВСЬКОМУ ДЕРЖАВНОМУ ПЕДАГОГІЧНОМУ ІНСТИТУТІ (1944-1953): ОРГАНІЗАЦІЙНІ ТА ЗМІСТОВІ АСПЕКТИ}

У статті представлено результати дослідження організаційних $і$ змістових аспектів освітньӧ̈ діяльності Львівського державного педагогічного інституту (далі - ЛДПІ) у 1944-1953 рр. Під час дослідження застосовувалися наукові методи: історико-гентичний, проблемно-хронологічний, історикотипологічний, історико-системний, аналізу й синтезу. Проаналізовано такі аспекти організації освітнього прочесу в ЛДПІ: графіки і змістові особливості навчання, студентська самостійна робота, педагогічна практика, виховання студентів. В інституті готували вчителів мови ілітератури (украйнської та російської), історії, фізики, математики, природничих дисииплін. Встановлено, щуо графіки навчального процесу, починаючи з 1944-1945 н.р. переважно не виконувалися. Значною проблемою до кіния 1940-х рр. в роботі всіх факультетів інститут була повна або часткова відсутність нових програм навчальних дисииплін, недостатнє забезпечення підручниками.

Ключові слова: освітній процес; вищза педагогічна освіта; Львівський державний педагогічний інститут; повсякдення; педагогічна практика.

Jim. 16.

Mykola Haliv, Doctor of Sciences (Pedagogy), Associate Professor of the History of Ukraine Department, Drohobych Ivan Franko State Pedagogical University

Oleksandra Sviontyk, Ph.D. (Pedagogy), Associate Professor of the General Pedagogy and Preschool Education Department, Drohobych Ivan Franko State Pedagogical University Myroslav Yushchyshyn, Masterjs Student, Drohobych Ivan Franko State Pedagogical University

\section{EDUCATIONAL PROCESS IN LVIV STATE PEDAGOGICAL INSTITUTE (1944-1953): ORGANIZATIONALAND CONTENT ASPECTS}

The article presents the results of research of organizational and contents aspects of educational activity of Lviv State Pedagogical Institute (hereinafter - LSPI) in 1944-1953. During the research scientific methods were used: historical-genetic, problem-chronological, historical-typological, historical-systemic, analysis and synthesis. The following aspects of the organization of the educational process in LDPI are analyzed: graphics and semantic features of training, independent training of students, pedagogical practice, ideological training of students. The institute trained teachers of language and literature (Ukrainian and Russian), history, physics, mathematics, and natural sciences. It is established that the educational process schedules, starting from 1944-1945 academic year, 